\title{
The Spatio-Temporal Interfaces within the Lesser Antilles Vegetation (The Example of the Island of Martinique)
}

\author{
Philippe Joseph \\ University of the French West Indies, UMR DEV SPACE-BIORECA, Schœlcher, Martinique \\ Email: joseph.phil@wanadoo.fr
}

Received 21 February 2016; accepted 5 March 2016; published 10 March 2016

Copyright (C) 2016 by author and OALib.

This work is licensed under the Creative Commons Attribution International License (CC BY). http://creativecommons.org/licenses/by/4.0/

c) (†) Open Access

\section{Abstract}

The temporal vegetation dynamics and its spatial distribution cause discontinuities, border areas, ecotones and ecosystem heterogeneities, in other words biocenotics which result in a multitude of shapes and organic combinations. These interfaces are added variations due to vertical stratification involving specific architectures and behaviours towards light. These "interface environments" represent a plurality of plant biodiversity aspects and therefore ecological profiles which form the basis of the resilience processes. In the Lesser Antilles, Man has increased community complexity by increasing the number of eco-units ${ }^{1}$. As a result, the number of ecosystem interfaces increased so in some ways, he became the "architect" or "creator" of species biodiversity in the landscape through the ecosystem and the plant communities. Ultimately the current landscape is a mosaic of physiognomic units of unequal dimensions belonging to various successional stages. In the case of Martinique, we will discuss the complexity of the Lesser Antilles forest vegetation. The argument seeks to show its hierarchical organisation, the characteristics of its subsets and their spatial and temporal relationships.

\section{Keywords}

Lesser Antilles, Martinique, Vegetation, Forest Ecosystem, Biodiversity, Anthropization, Interface, Ecotone

Subject Areas: Biodiversity, Biogeography, Ecology, Ecosystem Science, Environmental Sciences, Natural Geography, Plant Science

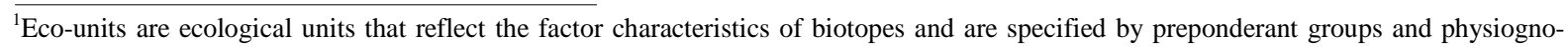
mies. 


\section{Introduction}

Despite the current landscape, characterised predominantly by herbaceous, shrub, and pre-forest units, the Lesser Antilles have forest ecosystem potentiality ${ }^{2}$ [1]. One of the reference points of this archipelago's history is the passage from an "original" vegetation dominated by forest species to cultivated fields consisting of exogenous anthropophyte plants and regressive floristic units composed mainly of shrubs, small trees and native grasses. The mountainous islands create orographic rainfall which varies from the low areas to the top. This rainfall gradient, whose structure differs from one mountain side to another, can roughly be divided into four bioclimates resulting in four potential forest types depending on their subtypes and characteristics (Figure 1). These different forest ecosystems delimit the plant floors and are specified by plant species and combinations.

In the light of recent studies, it seems that in the prehistoric times of the Lesser Antilles, the various plant coverage had reached maximum structural and architectural complexity and their floristic units were composed of highly specialized species from an ecological point of view. The edge of the forest developed formations which were unique both at floristic and biocenotic level. These are ecosystem interfaces created by the spatial overlapping of adjacent ecosystems. Highly layered, these pre-Columbian forest groups had arrived at the end of their evolution and had acquired a certain degree of autonomy from the macroclimate. In fact the exchange surfaces which constituted the crowns of the upper, middle and lower tree strata insulated the intra-forest environment from external fluctuations [2]-[4]. In the past these stratigraphic interfaces between the lower forest environment and the general climate favoured the demographic development of species which were highly specialized especially in their behaviour towards light energy [5]-[8].

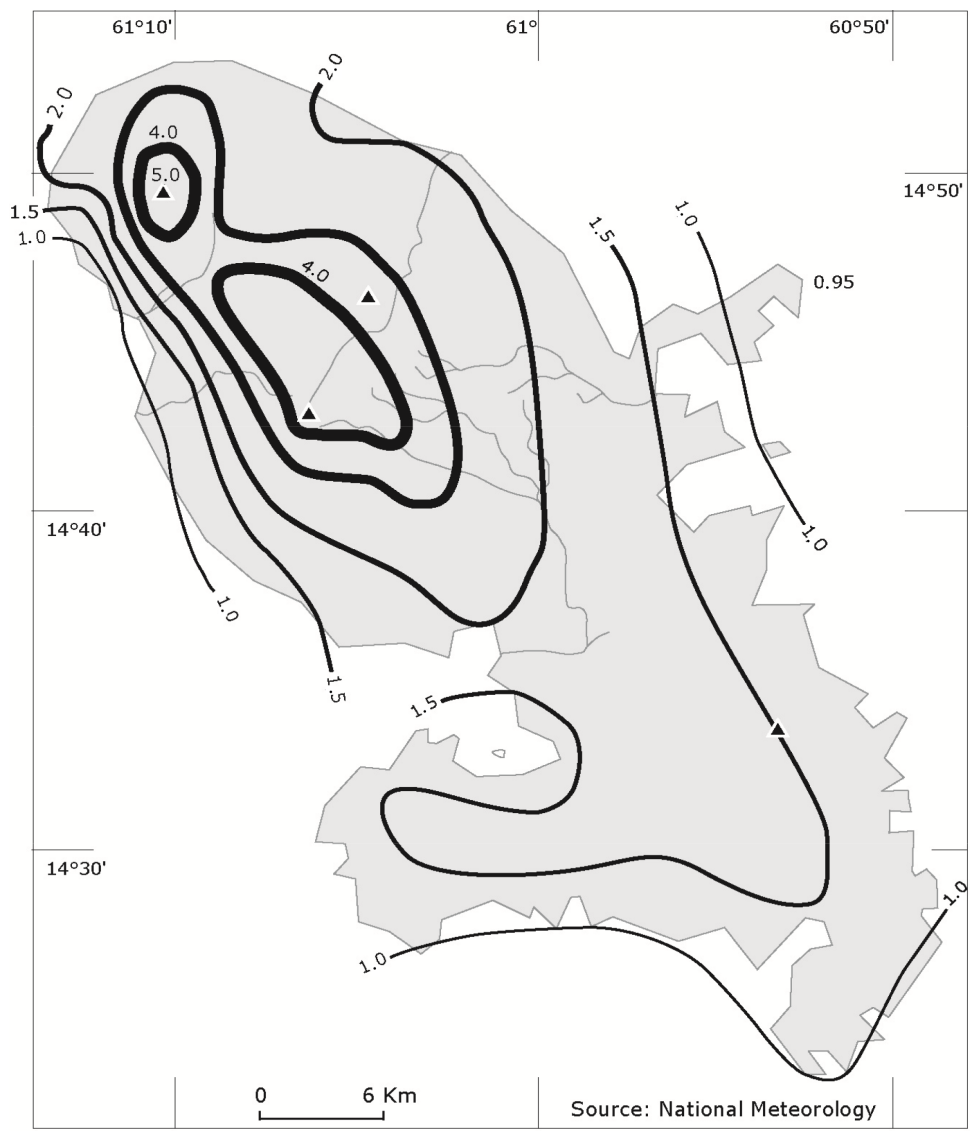

Dry bioclimate : annual rain fall $<1.5 \mathrm{~m}$

Middle-humid bioclimate : annual rain fall between $1.5 \mathrm{~m}$ and $2.5 \mathrm{~m}$.

Humid bioclimate: annual rain fall between $2.5 \mathrm{~m}$ and $4 \mathrm{~m}$.

Highly-humid bioclimate : annual rain fall $>4 \mathrm{~m}$.

Figure 1. The different bioclimate types of Martinique (P. JOSEPH modified).

${ }^{2}$ The term of plant succession in this part of the world has resulted in the establishment of forest formations. 
The present vegetation is seen as a mosaic of different temporal phases [9]-[12]. All the temporal sequences of the vegetation successions are present and correspond to transitional stages with regard to the climax ${ }^{3}$ [13] [14]. They can be considered successional intermediaries and represent just as many temporal interfaces [15] [16].

Ultimately, the ecotones (borders) between the large floristic groups, the multiple dynamic stages and their various strata create the plant coverage of the Lesser Antilles with its complex spatio-temporal interfaces [17][21]. Despite their small size, they are part of the amazing floristic diversity of the Lesser Antilles, which represent one of the 24 global biodiversity hot-spots: that of the Caribbean. For our case study, we will use Martinique's vegetation as reference because this island is subject to very strong human pressure, but nevertheless contains a large number of plant species and communities.

\section{The General Context}

Located at $14^{\circ} 30^{\prime}$ latitude North and $61^{\circ}$ longitude West, Martinique occupies a central position in the archipelago. It extends over $1090 \mathrm{~km}^{2}$ (65 km long and $35 \mathrm{~km}$ at its widest) and has openings as the Bay of Fort-deFrance and Robert Bay. It is a rugged island. Mount Pelée (1397 m), the Morne Jacob (884 m), the Pitons du Carbet whose peaks reach higher than $1000 \mathrm{~m}$ are the main mountain ranges. In the southern regions, the old volcano-sedimentary and volcanic complexes have a significantly softer terrain: the Vauclin Mountain is the highest one. There are also smaller mountains locally called hills, between which we see plains with various surfaces. The whole gives us a very varied landscape with slopes ranging from $2 \%$ to $50 \%$ while the average is around $20 \%$. Therefore the great diversity of the topographical aspects represents an important parameter in the establishment of plant communities.

The general climate of Martinique is characterised by two periods of varying duration: one accompanied by a significant decrease in rainfall (Lent), one characterised by a flow of more humid East winds (Wintering). The winter rains are increased by the orography and their quantity varies from the coast at the top of the mountains. All the bioclimatic and forest floors in the Lesser Antilles are represented. Today almost all vegetation is secondary. Due to human impact over time the forest has become "insular" and occupies barely $20 \%$ of the territory. Consisting primarily of shrub land, shrub and pre-forest communities, the contemporary vegetation is called regressive. There are few advanced, pre-climax and climax secondary units. Generally, the current flora is typical of open environments and is dominated by heliophile, semi-heliophile and semi-ombrophile species. Relic areas still allow species to reach the optimal phases of dynamic plant development (ombrophile and helio-ombrophile species) to reach all of their pheno-phases (phases of their life cycle) are located in remote areas of the foothills of the island's North mountains [10]. However, within the littoral and the inland forests (in the centre and South), there are marginal units with secondary stage late, pre-climax and climax species [10] [22]. By inference, all these remaining areas allow the reconstruction of the precolonial landscapes. They belong to the ombrophile tropical sub-montane type and the evergreen tropical seasonal type as well as to their tropical seasonal ombro-evergreen ecotone (Figures 2-4).

\section{Method}

Apart from the climate aspect, the following is an exercise in synthesis using data from the scientific literature. Indeed, the data of our predecessors such as [23]-[26], and as well as the recent works [1] [10] [11] [27]-[31], have allowed us to describe Martinique's structural and functional vegetation units. These data also allow us to assert that the observable physiognomic units in the current vegetation landscape represent as many degrees of biocenotic complexity, in other words dynamic stages [32] [33]. In these studies, the structural, architectural and spatiotemporal dynamic floristic descriptors taken into account regarding the conventional methodologies of botany, biogeography and ecology distinctively refer to autecology, synecology ${ }^{4}$ and chronology [34]-[38]. The floristic data were supplemented by measuring the climatic parameters. In fact, weather devices were installed in the open (witness) and within structured, pre-forest and shrub forest formations. While incomplete, the obtained data helped to highlight the effect of the exchange surfaces formed by the peaks of various the strata, on the macro-climate factors such as temperature, humidity and evaporation [39]-[41].

\footnotetext{
${ }^{3}$ It has a forest nature as in many regions of the intertropical zone.

${ }^{4}$ The autecology and synecology correspond respectively to the ecology of the species and communities they form.
} 


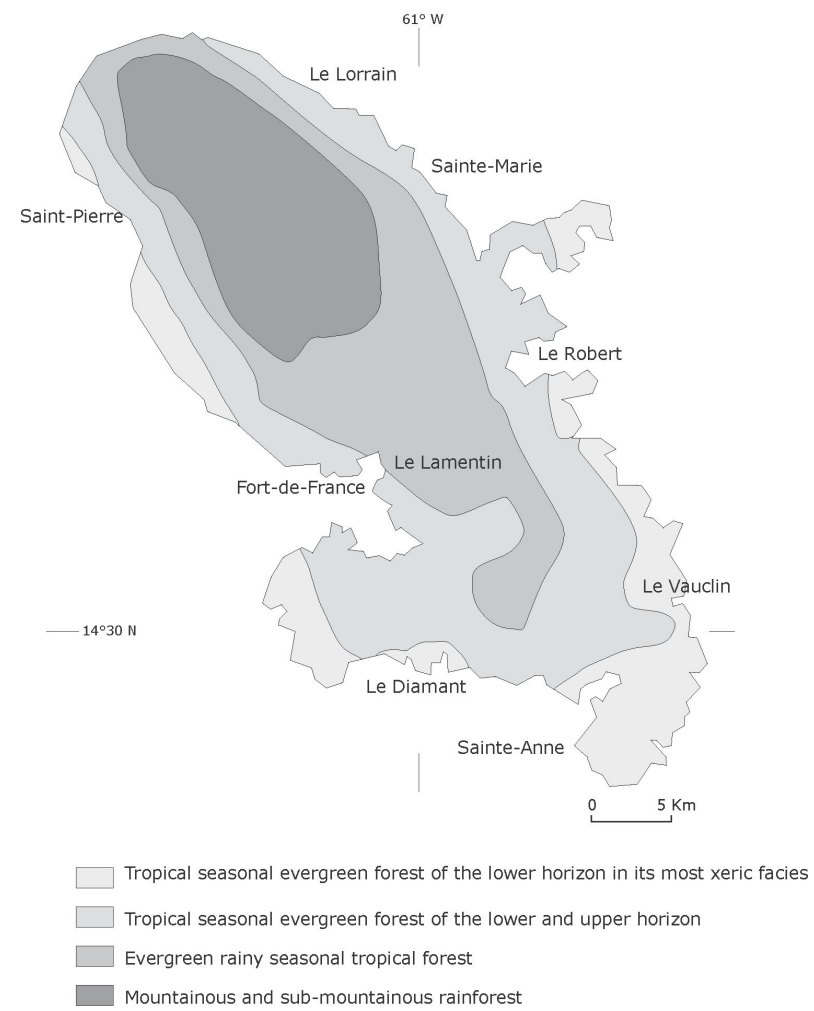

Figure 2. Martinique's vegetation in pre-Columbian times (Source: P. JOSEPH).

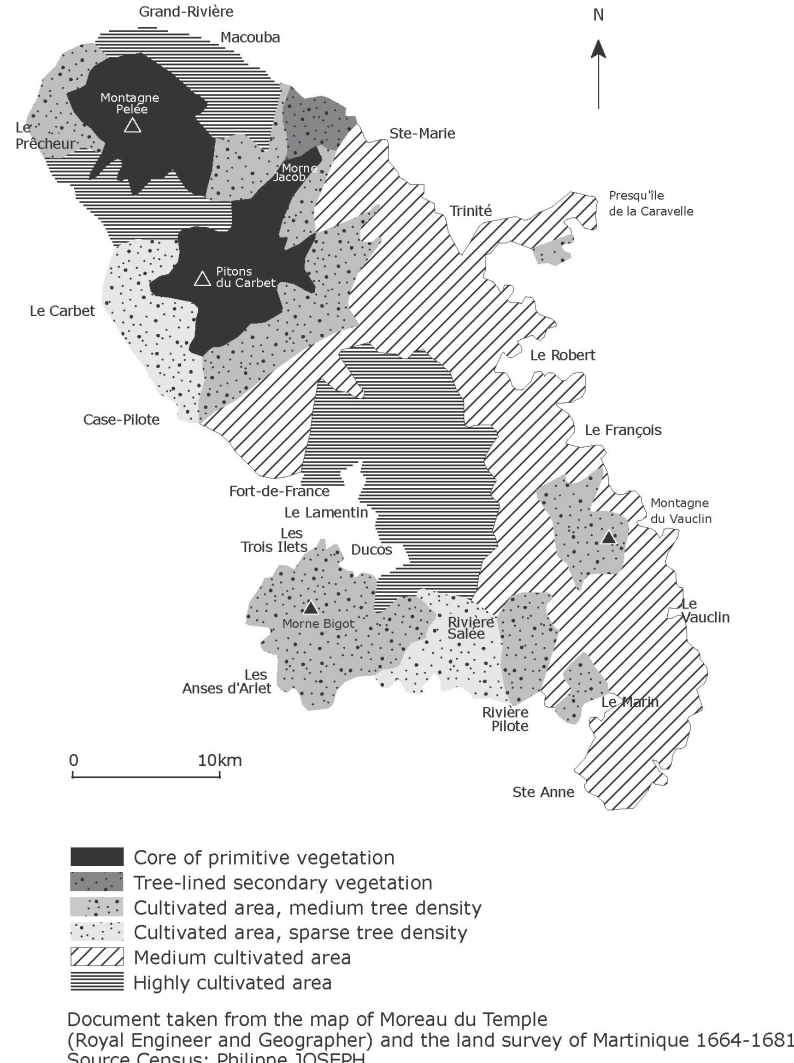

Figure 3. The vegetation state and structuring circa 1770 (Source: P. JOSEPH). 


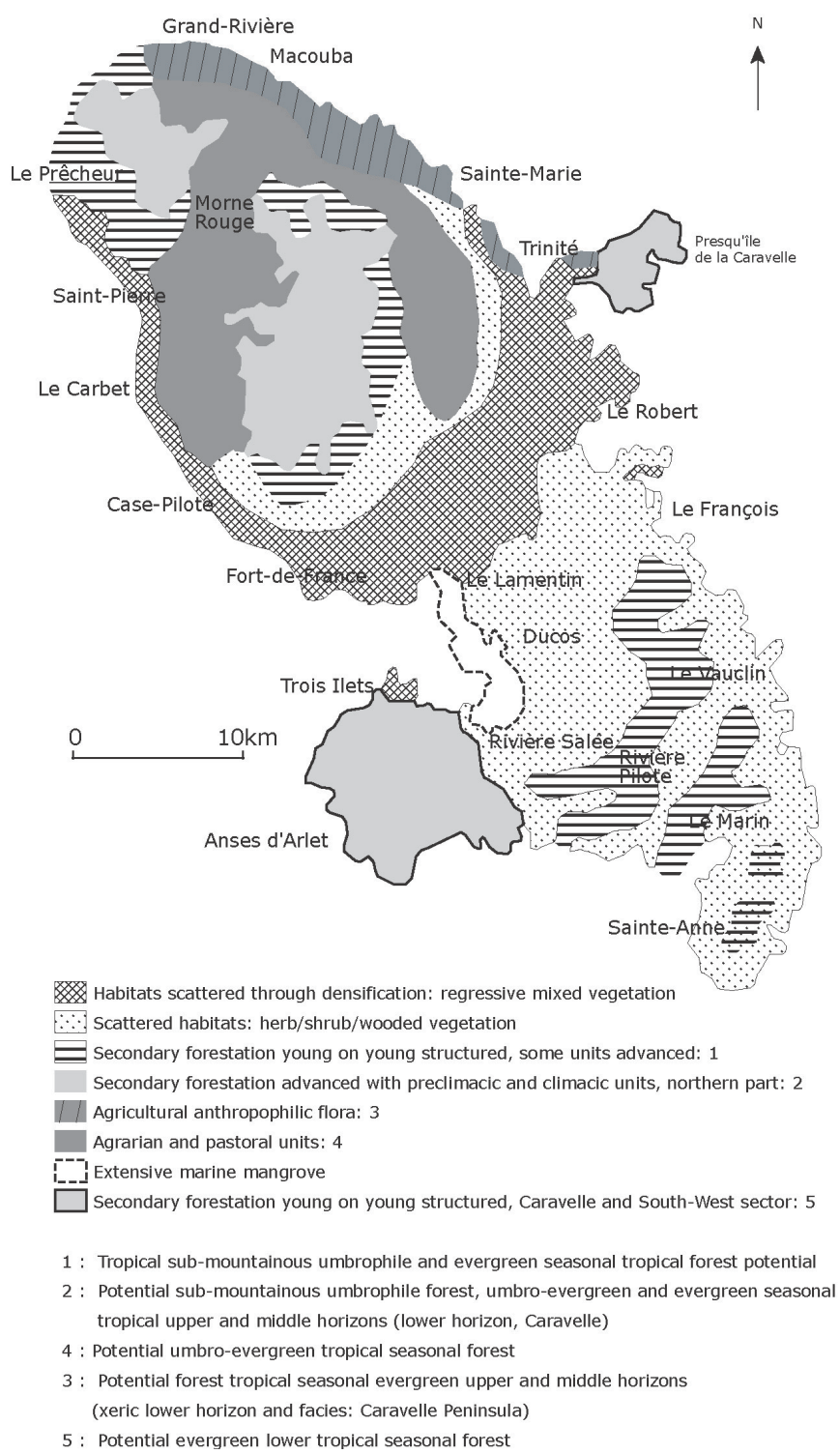

Figure 4. The present landscape (Martinique/ Source: P. JOSEPH).

\section{Results and Interpretations: General Synthesis}

\subsection{Some Data on Ecosystem Change}

It is quite plausible that prior to colonisation Martinique's vegetation was almost fully primitive and of the forest type [42]-[48]. Current data seem to confirm this hypothesis [22]. All the pre-Columbian forests of Martinique, like those of the other Lesser Antilles, consisted of pre-climax and climax floristic units. Unlike Mesoamerica and more widely the tropical America [49] the impact of the Native American people on the original forest ecosystems was very low. During the first contacts, the chroniclers described physiognomies and landscapes resulting from various combinations of highly specialized species in the final stages of vegetation dynamics [50]. In reality the pre-Columbian vegetation was divided into three plant floors at the end of their evolution. At the time the inhabitants practiced marginal burnt land agriculture at the lower level. Sometimes they ventured into remote areas to find and cut white gum trees (Dacryodes excelsa-Burseraceae) of important size which they shaped on the spot. Transported to the villages on the coast, they received the final touches before the boat was launched. These boats could carry fifty men and allowed long voyages in the Caribbean Sea, between the Islands and the Mainland. 
From sea level to the peaks we schematically see [10] [22] [51]: the evergreen seasonal tropical forest of the lower horizon which exhibits xeric features, the tropical seasonal evergreen forest, the sub-montane tropical ombrophile forest and the tropical montane ombrophile forest (Figure 2). At large scale these forest formations formed swaths which corresponded to the sub-humid dry, sub-humid damp, wet and hyper-humid bioclimatic areas (Figure 1). The plant floors were spatially solidary and their mass effect increased their resistance to severe weather (storms, hurricanes). The species space transfers were effective between these different floors. In fact, from their main areas the middle and upper species colonized the installation and expansion sites of certain formations of the lower floor and developed very low populations [10].

Nowadays, apart from the forest formations that cover the foothills of the mountains and a few areas of their lower third, everywhere the vegetation is regressive and dominated by pre-forest, shrub and herbaceous species. Due to various anthropization means, the present biocenotic net is dense, formed largely of secondary ecological units whose age, structure, floristic composition, physiognomy and dynamic stages are as varied as they are numerous. The units of this floristic mosaic generate many contacts areas where it is difficult to create ecological maps even at site level.

\subsection{The Contact Areas between the Plant Floors: Forest Ecotones}

Of course, logically, the interfaces between adjacent forest types and their horizons do exist [52]. These interfaces reach to the edge of the seasonal evergreen tropical and tropical ombrophile forests as well as that of the sub-montane ombrophile and montane tropical forests. They correspond respectively to the ombro-evergreen seasonal and ombro-ombrophile sub-montane forest. Although more difficult to identify, these ecosystem interfaces are also effective between the horizons of forest types: in particular between the lower and middle horizons (horizon type) of the tropical seasonal evergreen forest. Today, there are few examples of ecosystem continuum allowing us to precisely explore the forest ecotones. We were able to describe their global ecological characteristics only by using synchronic analysis ${ }^{5}$.

\subsubsection{The Tiering Generates Spatial Interfaces}

[25] proposed the forest xero-mesophilic and hygro-mesophilic ecotones. While improving the floral aspects, [30] used the same concepts in his doctoral thesis and they are still used nowadays. In the early 90s, in his work on the forest formations of the northeast of Martinique, [22] adapted the UNESCO nomenclature to the local context. In the light of analyses of approximately 300 floristic survey sites, he identified the semi-deciduous evergreen seasonal ecotone and the seasonal ombrophile evergreen ecotone. To these forest contact areas we must add those which signal the passage from the sub-montane ombropile forest to the montane ombrophile forest: the ombro-ombrophile sub-montaneecotone (Philippe JOSEPH, personal unpublished data). Previous designations are ecosystem equivalents corresponding to two distinct classifications, one old and regional designed by [25] and revisited by [30], the other one defined by [51], fairly recent and universal in its outlines. Despite the difficulties of small scale use, the UNESCO forest classification enables comparisons. We have increased the relevance of the ecosystem description by adding the slope, the floristic potentiality and the stage of development [10] (Figure 5, Table 1).While we can prove the existence of the seasonal ombro-evergreen ecotone, we cannot say the same for the semi-deciduous - evergreen tropical seasonal ecotone. In fact, in the Lesser Antilles, the existence of this potential semi-deciduous forest type [31] in the tropical dry season has not been demonstrated, not even in the low islands such as the Grande-Terre of Guadeloupe, Marie-Galante, les Saintes, la Desirade, Saint-Barthelemy, etc. And according to the new data [10] [22] the current formations are regressive forms of the climax tropical seasonal evergreen forest which from a phenological as well as a physiognomic point of view is related to the semi-deciduous forest during the tropical dry season as defined by UNESCO. The woody species of xerophytic environments are well represented [for example Eugenia confusa (Myrtaceae) and Randia aculeata (Rubiaceae)] and 50\% of them are deciduous [10] [22].

\subsubsection{The General Characteristics of the Tropical Seasonal Ombrophile Evergreen Forest}

Unlike other ecotones, the tropical seasonal ombrophile evergreen forest is spatially well represented, both in its climax phase (Figure 2) and in its regression stage (Figure 3). Its floristic, biocenotic and structural identification

\footnotetext{
${ }^{5}$ However, differences in levels of development and therefore complexity due to human impact can distort the ecological characterization of these ecotones.
} 


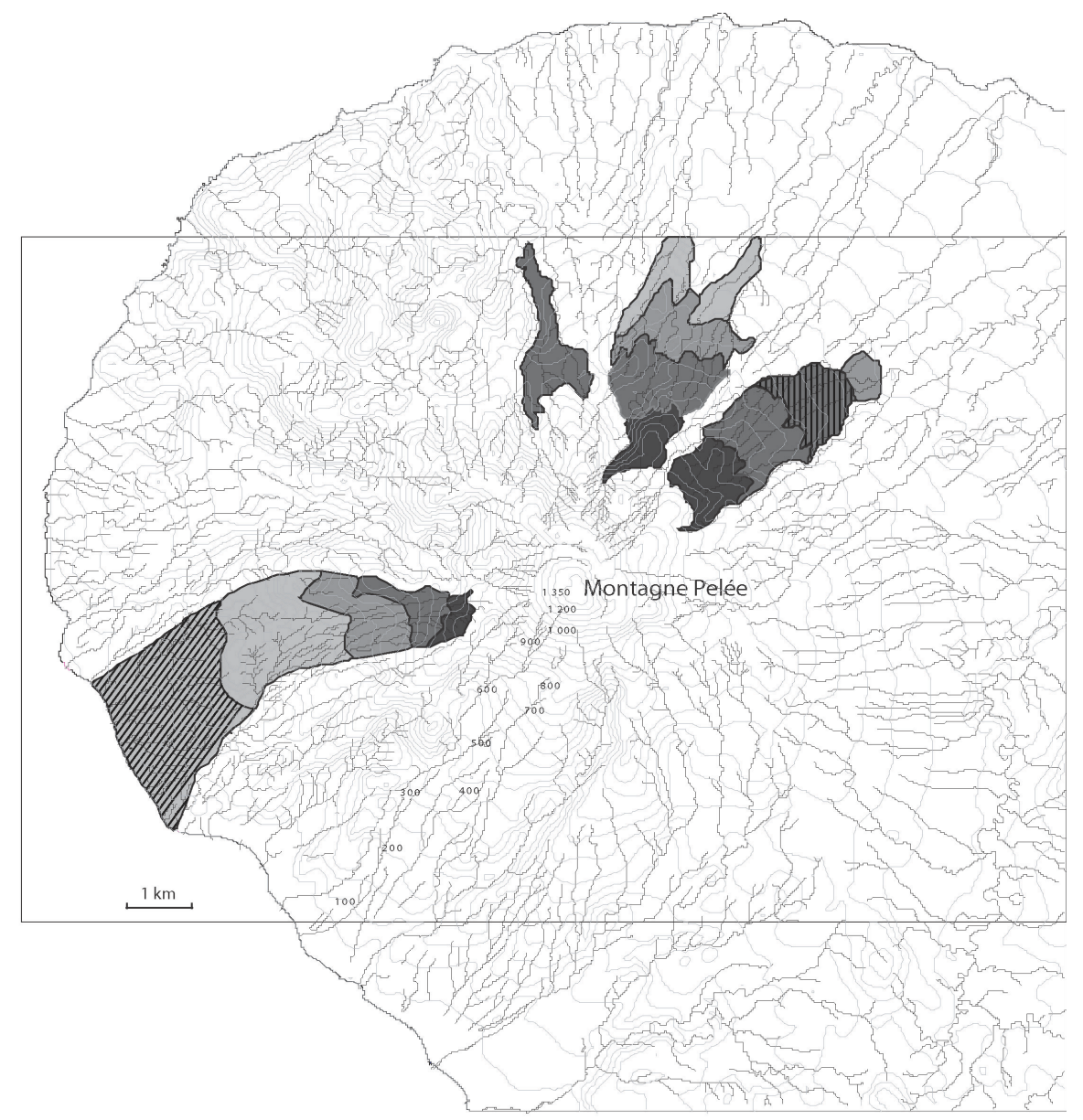

Forestry layering (Ecosystem gradient)
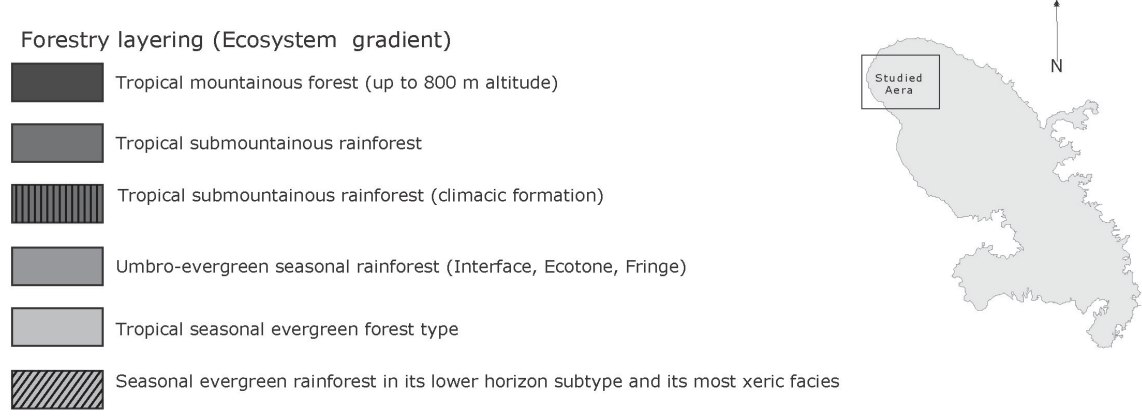

Figure 5. Ecosystem gradient and ecotones (the example of Martinique/Source: P. JOSEPH).

Table 1. The main species of the late seasonal ombro-evergreen forests in Northern Martinique (Source: P. JOSEPH).

\begin{tabular}{|c|c|c|c|c|c|}
\hline Taxa/families & Vernacular names & $\begin{array}{l}\text { Qualitative } \\
\text { prevalence }\end{array}$ & $\begin{array}{c}\text { Ecological } \\
\text { strategy }\end{array}$ & $\begin{array}{l}\text { Dynamic } \\
\text { stages }\end{array}$ & $\begin{array}{c}\text { Ecosystem-based } \\
\text { affinity }\end{array}$ \\
\hline Guatteria caribaea & Corossol grand bois & $\mathrm{R}$ & M & FST, FPC, CF & OBS \\
\hline Oxandra laurifolia & Bois de lan & $\mathrm{TR}$ & M & FT, FPC, CF & Ecotone OBS - SS \\
\hline Tabernaemontana citrifolia & Milkwood & $\mathrm{R}$ & $\operatorname{Tr}$ & FS & OBS \\
\hline Prestoea montana & Palm & TAB & $\mathrm{M} \& \mathrm{Ch}$ & FS, FST & OBS \\
\hline Quararibea turbinata & Lele tree & TAB & $\mathrm{M} \& \mathrm{Ch}$ & FS, FST & SS \\
\hline Hirtella triandra & Hairy Zicaque & $\mathrm{TR}$ & M & FST, FPC, CF & OBS \\
\hline Tapura latifolia & Bois-cote & $\mathrm{R}$ & M & $\mathrm{FPC}, \mathrm{CF}$ & OBS \\
\hline Sloanea caribaea & Acomat boucan & $\mathrm{R}$ & M & FPC, CF & OBS \\
\hline
\end{tabular}




\section{Continued}

\begin{tabular}{|c|c|c|c|c|c|}
\hline Sloanea dentata & Large leaf chestnut & TAB & M & FST, FPC, CF & OBS \\
\hline Sloanea massoni & Small leaf chestnut & $\mathrm{R}$ & M & FST, FPC, CF & OBS \\
\hline Erythroxylum squamatum & Red seeds & $\mathrm{R}$ & $\mathrm{M} \& \mathrm{Ch}$ & FS & OBS \\
\hline Sapium caribaeum & Glue tree & $\mathrm{AB}$ & $\mathrm{M} \& \mathrm{Ch}$ & FS & OBS \\
\hline Dussia martinicensis & Bois la gamelle & $\mathrm{AB}$ & $\mathrm{M} \& \mathrm{Ch}$ & FS & OBS \\
\hline Lonchocarpus pentaphyllus & Savonette grand bois & $\mathrm{AR}$ & $\mathrm{CH}$ & FS & OBS \\
\hline Ormosia monosperma & Red Caconnier & $\mathrm{AB}$ & M & FS, FST & SS \\
\hline Inga ingoides & Hairy sweet peas & $\mathrm{R}$ & $\mathrm{Ch}$ & FS & OBS \\
\hline Casearia decandra & Egg yolk & $\mathrm{R}$ & $\mathrm{Ch}$ & FS & SS \\
\hline Homalium racemosum & Hybrid Acomat & $\mathrm{TR}$ & $\mathrm{Ch}$ & FS, FST & PEMS \\
\hline Aniba bracteata & Yellow Laurel & TAB & M & FS, FST & OBS \\
\hline Ocotea cernua & Isabelle Laurel & $\mathrm{R}$ & $\mathrm{M} \& \mathrm{Ch}$ & FS, FST & SS \\
\hline Ocotea dominicana & Okra Laurel & TR & $\mathrm{Ch}$ & FS & SS \\
\hline Ocotea leucoxylon & Fine Laurel & $\mathrm{TAB}$ & M & FPC, CF & OBS \\
\hline Ocotea martinicensis & Laurier-root & $\mathrm{R}$ & M & FS, FST & SS \\
\hline Ocotea patens & Gros grain laurel & $\mathrm{R}$ & $\mathrm{Ch}$ & FS & OBS \\
\hline Cinnamomum elongatum & Cinnamon Laurel & $\mathrm{R}$ & $\mathrm{Ch}$ & FS, FST & PEMS \\
\hline Talauma dodecapetala & Pine tree & TR & M & FPC, CF & OBS \\
\hline Guarea glabra & Gun tree & TR & M & FPC, CF & SS \\
\hline Guarea macrophylla & Gun tree & $\mathrm{TAB}$ & M & FPC, CF & Ecotone OBS - SS \\
\hline Trichilia pallida & Black chestnut & $\mathrm{R}$ & $\mathrm{M} \& \mathrm{Ch}$ & FS & SS \\
\hline Ficus americana & The small leaf fig tree & TR & $\mathrm{CH}$ & FS & OBS \\
\hline Ficus insipida & AgoutiFig tree & TAB & $\mathrm{M} \& \mathrm{Ch}$ & FS, FST & OBS \\
\hline Stylogyne canaliculata & Bois-petite chique & AR & M & FST, FPC, CF & OBS \\
\hline Eugenia gregii & Ash tree & $\mathrm{R}$ & M & FS, FST, FPC & SS \\
\hline Eugenia pseudopsidium & Hybridguava & $\mathrm{R}$ & $\mathrm{M} \& \mathrm{Ch}$ & FS, FST & SS \\
\hline Myrcia fallax & Hybridguava & $\mathrm{R}$ & $\mathrm{M} \& \mathrm{Ch}$ & FS, FST & SS \\
\hline Plinia pinnata & Nutmeg tree & $\mathrm{R}$ & M & FS, FST & OBS \\
\hline Pisonia fragrans & Mapou & TR & $\mathrm{Ch}$ & FS & SS \\
\hline Piper reticulatum & Rat tail & AC & $\mathrm{Ch}$ & FS & OBS \\
\hline Heisteria coccinea & Partridge tree & $\mathrm{R}$ & M & FS, FST, FPC & OBS \\
\hline Cassipourea guyanensis & Garlic tree & TR & M & FS, FST & SS \\
\hline Chimarrhis cymosa & River tree & TAB & $\mathrm{M}$ & FS, FST, FPC & OBS \\
\hline Faramea occidentalis & Arrow tree & $\mathrm{TR}$ & $\mathrm{M} \& \mathrm{Ch}$ & FS, FST & SS \\
\hline Ixora ferrea & Coffee-tree & $\mathrm{R}$ & $\mathrm{M} \& \mathrm{Ch}$ & FS, FST & SS \\
\hline Psychotria mapourioides & Coffee-tree & $\mathrm{R}$ & Ch & FS & OBS \\
\hline Psychotria tenuifolia & Brown Coffee & $\mathrm{R}$ & $\mathrm{Ch}$ & FS & OBS \\
\hline Zanthoxylum caribaeum & White pine & TR & $\mathrm{Ch}$ & FS & SS \\
\hline Chrysophyllum argenteum & Petit boui & TR & M & FS, FST, FPC & SS \\
\hline Micropholis guyanensis & Golden leaves & $\mathrm{TR}$ & M & FST, FPC, CF & OBS \\
\hline Pouteria multiflora & Gingerbread & $\mathrm{R}$ & M & FST, FPC, CF & OBS \\
\hline Pouteria semecarpifolia & Contrevent & $\mathrm{R}$ & M & FST, FPC, CF & OBS \\
\hline Simarouba amara & White wood & $\mathrm{AR}$ & $\mathrm{M} \& \mathrm{Ch}$ & FS, FST & OBS \\
\hline Cestrum laurifolium & Forest Jasmine & $\mathrm{AR}$ & $\mathrm{Ch}$ & FS & OBS \\
\hline Sterculia caribaea & Machot-pig & AR & M & FS, FST & OBS \\
\hline Philondendron scandens & Siguine (epiphyte) & & M & FS, FST, FPC, CF & OBS \\
\hline Amphilophium paniculatum & Boat vine (vine) & & M & FS, FST, FPC, CF & Ecotone OBS - SS \\
\hline Macfadyena unguis-cati & Cat claw (vine) & & M & FS, FST, FPC, CF & Ecotone OBS - SS \\
\hline Petrea kohautiana & Great vine (vine) & & $\mathrm{Ch}$ & FS, FST & SS \\
\hline
\end{tabular}

R: Rare; TR: Very Rare; AR: fairly rare; TAB: Very abundant; AB: abundant; AC: Fairly common; M: Forest Matrix; Ch: Chablis; FS: Secondary Forest; FST: Late or advanced Secondary Forest; FPC: Pre-climax forest; CF: Climax forest; OBS: Sub-mountain ombrophile; SS: Evergreen seasonal. 
criteria are also very specific. It is a contact environment where the humid and sub-humid wet bioclimates overlap and it also contains the vegetation of the lower horizon of the sub-montane ombrophile forest and that of the upper horizon of the tropical seasonal evergreen forest (Figure $1 \&$ Figure 2). Actually like all ecotones, this group offers a partial mix of both forest types (Table 1). Among the dominant climax or sub-climax species we mention Sloanea dentata (Big leaf Chestnut) and the Chimarrhis cymosa (River tree) for the sub-montane ombrophile forest, Ocotea leuxoxylon (Fine laurier) and Ormosia monosperma (Caconnier) for the seasonal evergreen forest [22]. The ecological forest edge species are joined by others that characterize the ecotone. They are few in number, nevertheless they are indicators of the transition between two bioclimatic floors (between two plant floors), in this case the middle and lower floor. Cherimolia ternatensis (Devil tree), Guarea marophylla (the gun tree), Quararibea turbinata (the lélé tree) and Stylogyne canalicuta (bois petite chique) are among the most significant. The latter taxon is a relevant bio-indicator because it is inseparable from the climax. Vines, herbs and epiphytic or terrestrial ferns also exhibit the same interference of ombrophile and evergreen taxa. Indeed, the typical vines of the seasonal evergreen forests, such as Amphilophium paniculatum (the boat vine), Macfadyena unguis-cati (the cat claw vine) and Petrea kohautiana (big vine), those of the sub-montane ombrophile forests such as Marcgavia umbellata (the josé tree) and the Philodendron scandens cover the same trees. Sometimes they throw ramifications withcentimetre-thick sectionsfrom the crowns of the upper and middle strata. The undergrowth is frequently colonized by low populations of herbaceous species ${ }^{6}$ which are purely ombrophile in nature, including the Thelypteris reticulata and the Sélaginelle (Selaginella flabellata) ferns.

From a structural and architectural point of view, in its mature stage, the ombro-evergreen tropical seasonal forest is closer to the sub-montane ombrophile forest. Nevertheless it retains some traits of the seasonal tropical evergreen type. They are equivalent in their overall appearance. The generally hooped peaks are evergreen: the canopy is always green. Only a few species marginal in biomass and density lose their leaves during the dry season which, occurring at the interface of the sub-humid humid and sub-humid dry bioclimates, is very short or non-existent. The main ones are Dussia martinicensis (bois-gamelle), Ceiba pentandra (Fromager), Lonchocarpus pentaphyllus (Savonette grand-bois) and Vitex divaricata (Bois-lezard). Compared to the seasonal evergreen tropical forest the trees have a greater average distance of exclusion. They are between 30 and 40 meters high and have powerful buttresses. These, like the Slonea, Dussia, Ceiba and Chimarrhis genera give these "juggernauts" a very stable footing. As for the other forest types, the structuring trees of the final stages of this ecotone are more resistant to hurricanes. The herbaceous stratum is mainly occupied by more ombrophile species ${ }^{7}$ such as the terrestrial ferns (example: Thelypteris reticulata, Polybotria cervina) and the Clyclantacees (example: Asplundia rigida, Asplundia dussii).

The regressive forms of this forest type are plural. Most ombrophile species disappear before those of the secondary evergreen tropical seasonalgroups. Somehow, the forest canopy opening favours an increase inpioneer or secondary taxa of the middle floorupper horizon.

Ultimately, it seems that in marginal are as the mature tropical seasonal ombro-evergreen ecotone corresponds to an extension of the species of the lower horizon of the sub-montane ombrophile forest to the upper horizon of the evergreen seasonalforest. Conversely after the anthropogenic or natural degradation the species of the upper horizon of the seasonal evergreen forest colonize the lower horizon of the sub-montane ombrophile forest (Figure 2).

\subsection{Successional Intermediaries: Temporal Interfaces}

In the Lesser Antilles the anthropization diversified in frequency and intensity has produced a dense floral mosaic. Irrespective of their bioclimatic classification, the multiple landscape units result from the regression of the almost primitive and climax pre-Columbian forests. Today the shrubland, herbaceous, shrub and pre-forest phytocenoses develop alongside young secondary forest communities and rare advanced or climax forest relics. These physiognomic types represent as many stages of evolution and degrees of ecosystem complexity. During a gradual evolution, all transitional phases determine the optimal forest organisation at structural and architectural levels as well as at biocenotic level. As a result, the dynamic or successional gradient composed of stages, phases or chronologies is divided into two periods: the extra-forest successional cycles and intra-forest succes-

\footnotetext{
${ }^{6}$ They are often species with broad leaves adapted to the crepuscular conditions of the undergrowth.

${ }^{7}$ In the undergrowth of the tropical seasonal evergreen forest the herbaceous species such as the Bois-genou (Odontonema nitidum) are very abundant.
} 
sional cycles (Figure 6). In reality these cycles delimit two unique bio-systemic stages. They correspond, respectively, to a degree of greater complexity (the climax forest) and low complexity (the herbaceous stage) below which the ecosystem disappears as such. We were able to identify eleven dynamic stages which correspond to strict ecosystem characteristics (Figure 6): the herbaceous Formations ${ }^{8}$ the Shrubbery, the mature Shrubbery, the shrub Formation, the mature shrub Formation, the pre-forest Formation, the structured young forest Formation, the secondary forest Formation, the late secondary forest Formation, the pre-climax forest Formation and the climax forest Formation.

All the ecological profiles can be found in the floristic potential ${ }^{9}$. These refer to affinities for bioclimates and even biotic or environmental factors. The light seems to be the most relevant factor to consider. Close to the climax the species become increasingly ombrophile, particularly those of the medium and low forest strata. On the contrary, the regression of a mature forest translates into the progressive establishment of increasingly heliophile taxa. Irrespective of the bioclimate, the vegetation dynamics translates into physiognomic and floristic, structural and architectural changes. The vegetation's internal environment is also affected by significant factor changes, particularly temperature, evaporation, humidity and saturation deficit. From the shrubbery stage to the climax forest stage we move from morpho-type shrubs which are low and weakly branched to morpho-types of highly branched trees, some of which may peak at over 40 metres, passing through all the shrub morpho-types. These physiognomic changes are accompanied by a floristic succession corresponding to a succession of ecological profiles. The successive phytocenoses consist of species more specialized for the various biophysical factors. Thus, during the vegetation dynamics we successively see the development of the first rank heliophiles ${ }^{10}$ the second rank heliophiles, the semi -heliophiles, the semi-ombrophiles, the ombrophiles, and finally the helioombrophiles.

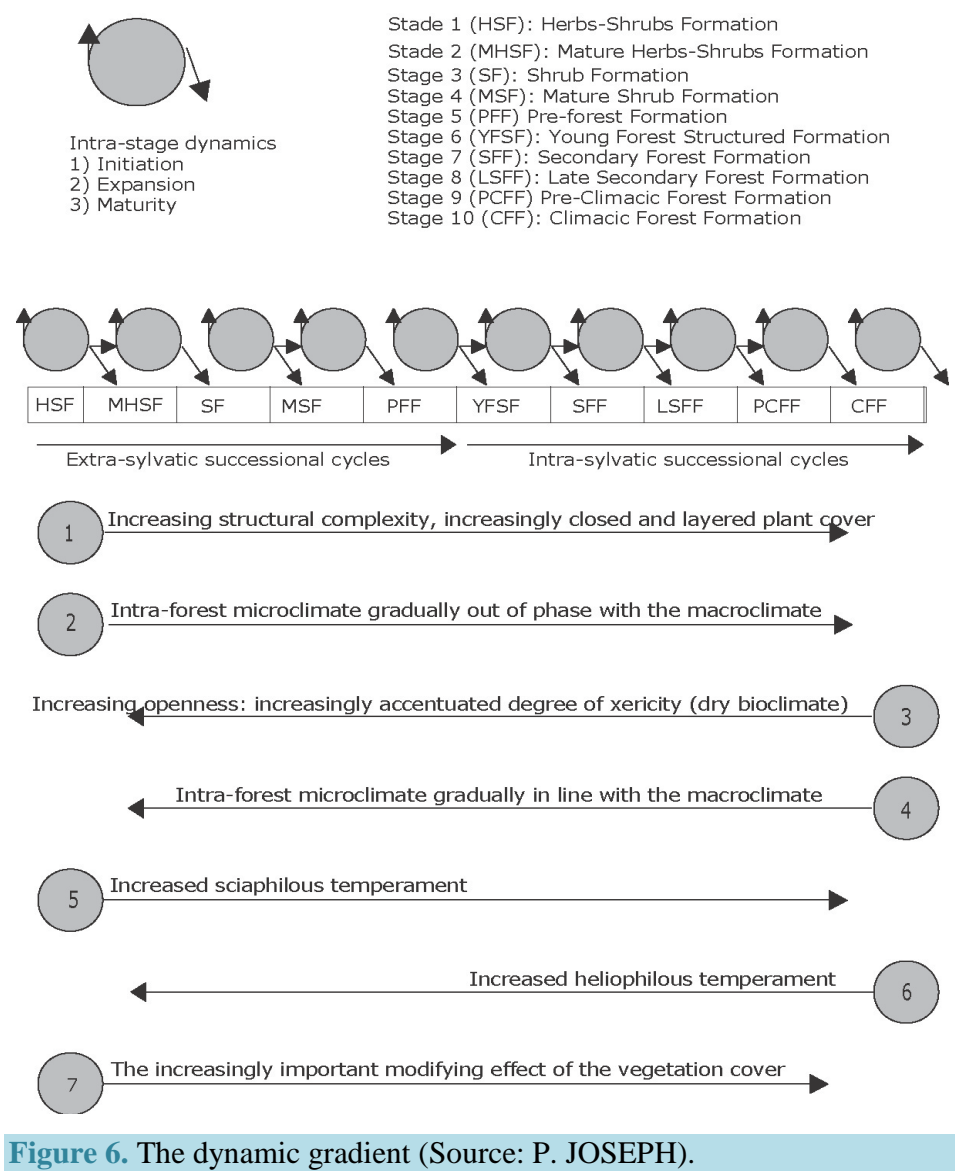

\footnotetext{
${ }^{8}$ In Figure 6, the herbaceous formation is not represented: it is also characterized by complex cycles. ${ }^{9}$ The collection of plant species, the stock or species fund.

${ }^{10}$ Those that appear with the first waves of floristic colonization.
} 
A dynamic stage consists of a succession of three events: the initiation, expansion and maturity (Figure 6). This intra-stage dynamic allows the passage from a successional stage to another. For example, in the adult shrub formations, the shrub species appear in small numbers. Marginal at the beginning ${ }^{11}$ they regularly increase their density and biomass ${ }^{12}$ as they move closer to the pre-forest stage. In the mature phase of the shrub stage, the shrubs are dominant and occupy almost all of the installation and expansion sites ${ }^{13}$. As a general rule, the species of a stage in its maturity phase optimise the installation of the plants that will take precedence in the next stage. All the dynamic stages as well as their internal phases are vegetation evolution stages, all of which represent temporal interfaces.

\subsection{The Exchange Surfaces of the Vegetation's Vertical Stratification: The Interfaces between the External Environment and the Intra-Vegetation Environment}

\subsubsection{The Architectural and Structural Changes during Plant Succession}

The average height of the plant eco-units, their architectural organisation and biomass vary significantly especially from themono-layer regressive phases to the advanced forest phases with three or four strata or exchange surfaces, sometimes even five in old-growth forests [53]. The result is an increasingly strong physical constraint reflected by the progressive rise of the morphological inversion level (the first branches, Figure 7(a)): especially for the upper and middle strata trees (the elective or structuring ones). The progressive dynamics is characterised by a succession of physiognomic types. In order of importance we see: the nanophanerophytes (from 0.5 to $2 \mathrm{~m}$ ), the microphanerophytes (from 2 to $8 \mathrm{~m}$ ), the mesophanerophytes (from 8 to $25 \mathrm{~m}$ ), the macrophanerophytes (from 25 to $40 \mathrm{~m}$ ), the megaphanerophytes ( $>40 \mathrm{~m}$ ). Until the late secondary forest stage characterised by joined crowns forming a nearly continuous roof, the vegetal coverage is discontinuous and presents a low number of exchange surfaces. For example in weakly structured young secondary stages, the forest communities are little structured. They have a roof with gaps which nevertheless catches much of the incident energy (Figure 7(b)).

\subsubsection{The Intra-Vegetation Microclimate: The Example of the Lower Floor}

The vegetation'sgradual evolution leads to floristic, physiognomic and landscape changes, but also to microclimatic ones. In other words, the plant structure is the initiator of the intra-vegetation microclimate by modifying the macro-climate factors more specifically in its lower part, between 0 and $2 \mathrm{~m}$ [54] [55]. This essential area for maintaining the formation in place transforms with the evolution of the vegetation cover. This vegetation regulatory force gradually evolving towards its optimal stage first serves to protect the regeneration from too strong factorial variations which are harmful for their survival (Figure 8). In the indoor environments of forest formations (including the oldest), the macroclimate fluctuations are not eliminated. They are more or less damped in space and time depending on the density of the exchanging surfaces formed by the leaf surfaces (Figure 7). Compared with a control station, the measurements at $2 \mathrm{~m}$ from the ground, within various plant formations in the same bioclimatic conditions, clearly show the modifying effect of the forest architecture on the main climate factors (except rainfall): temperature, humidity, and evaporation (Figures 8(a)-(e)). From the pioneer to the climax stage, there seems to be a gradual shift between the general climate and the intra-vegetation environment. Its purpose is a more efficient water resources management.

\section{Conclusion}

The vegetation cover in the Lesser Antilles is a true laboratory for the study of ecosystem interfaces. From a time or space point of view, they are characterised by specific plant communities. The eco-units that comprised the pre-Columbian forest formations were identical in age and sometimes had a different floristic composition. Their contact areas showed little variation. In contrast, the edges of climax forests and those that existed within the latter between the matrix and the gaps (chablis) ${ }^{14}$ were clearly differentiated. From the beginning of colonization to the present day human activities had contributed to the increase in biocenotic interfaces. The climax and subclimax forests of the Amerindian period had gradually been replaced by herbaceous, shrub and pre-forest

\footnotetext{
${ }^{11}$ The initiation phase.

${ }^{12}$ They optimize their ability to use the resources of the environment: this is the expansion phase.

${ }^{13}$ A plant community is a microsystem consisting of basal units named nano-systems [10]. The nano-system can be likened to the plant and its corresponding ground volume: it is its installation and expansion site. Within the latter all the plant's phenological phases take place.

${ }^{14}$ The gaps (characterized by secondary species) in relation to the forest matrix (composed of climax eco-units) are very marginal.
} 


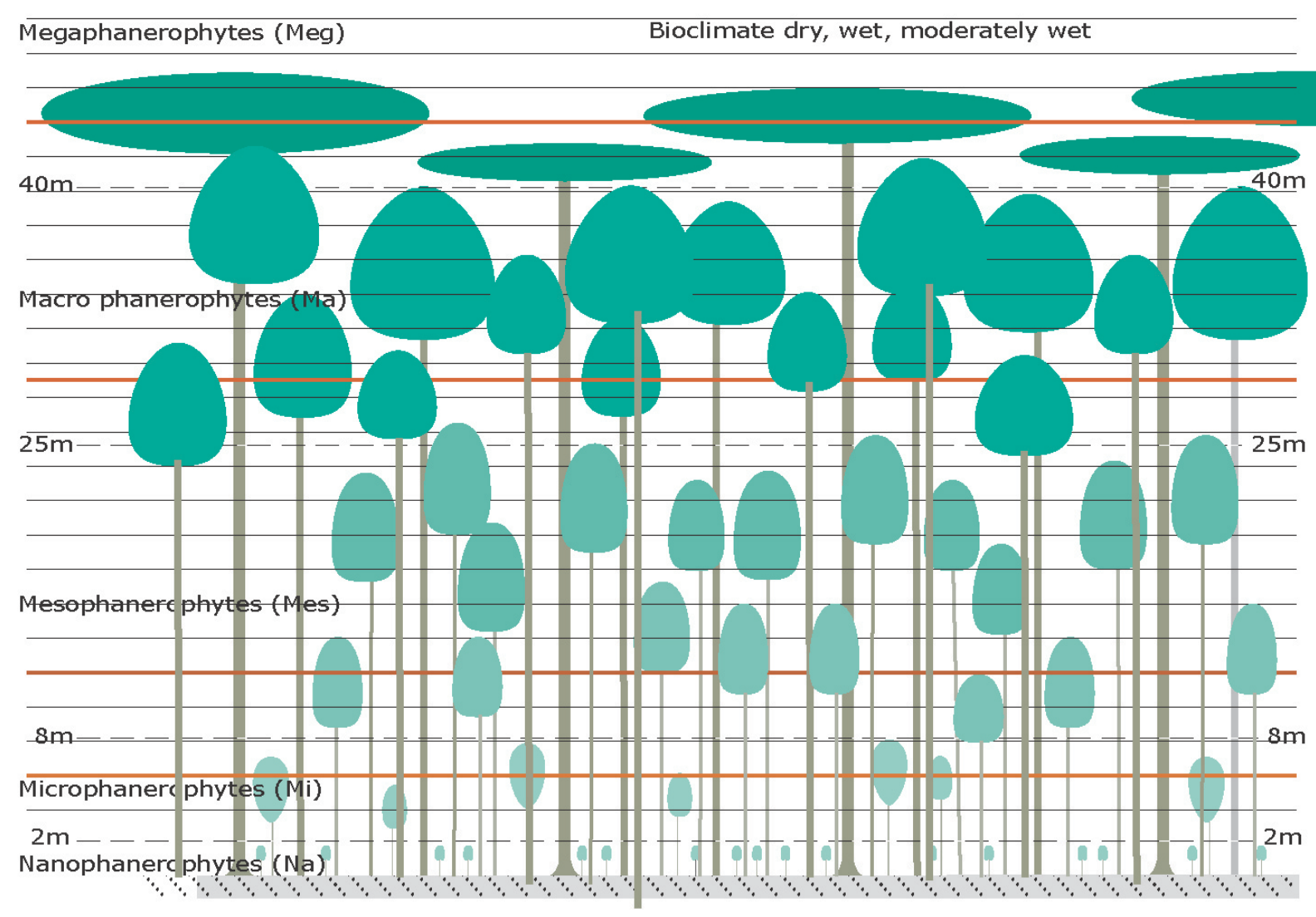

(a)

$25 m$

$25 \mathrm{~m}$

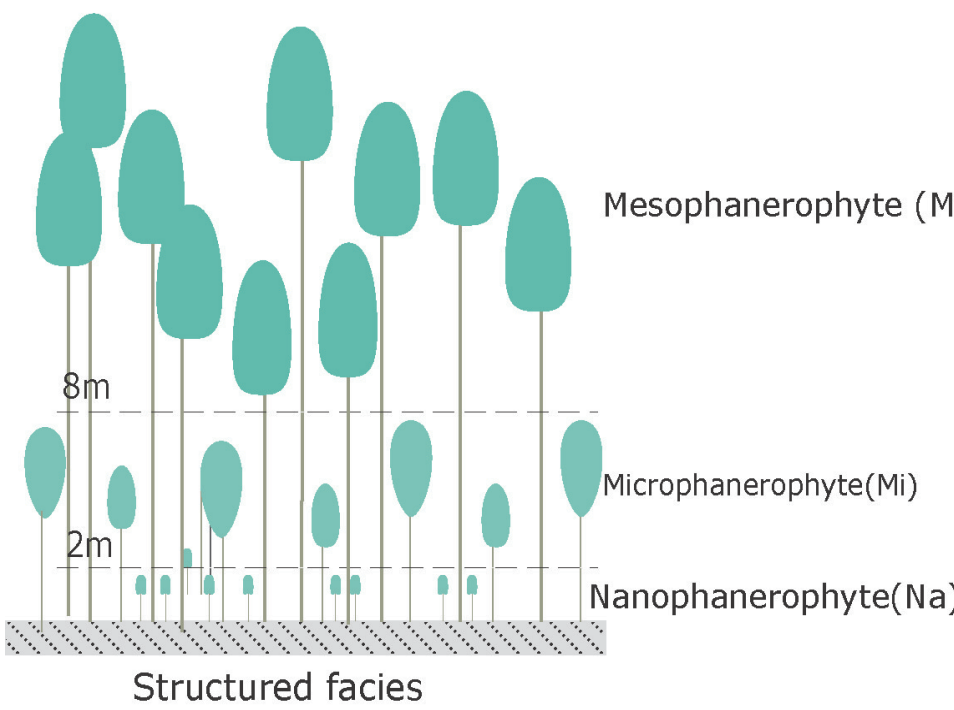

(b)

Figure 7. (a) Primary forest (synthesis of an eco-unit plan/Source: P. JOSEPH); (b) secondary forest (synthetic figure/ Source: P. JOSEPH). 


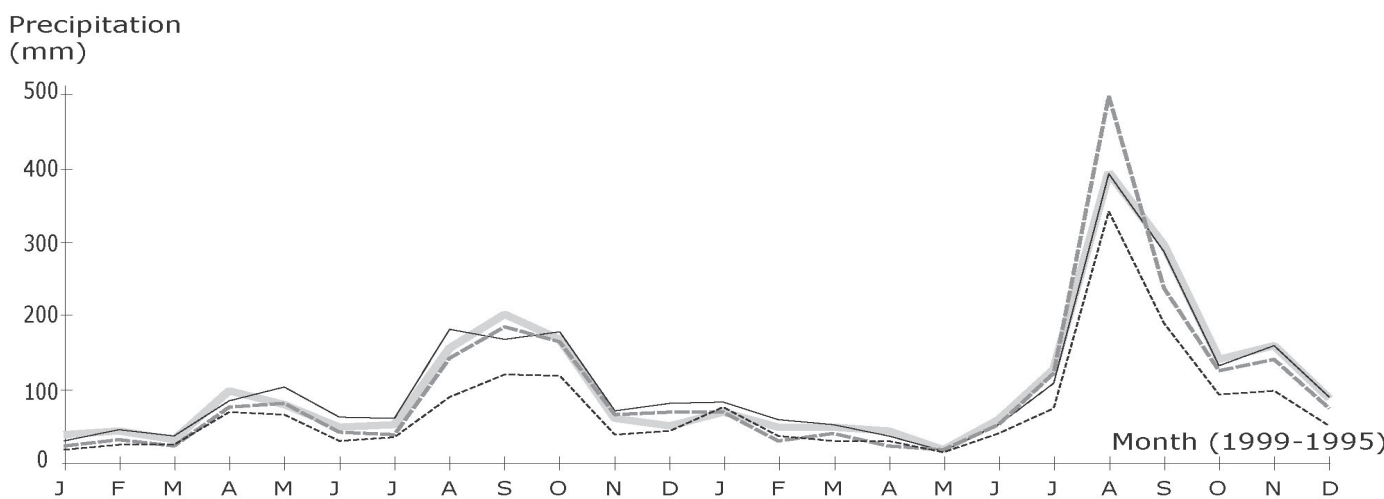

Station a: signal (fully uncovered)

---- Station b: preforest formation

--- Station c: secondary forest structured formation

Station d: shrub formation

(a)

Evaporation ( $\mathrm{mm})$

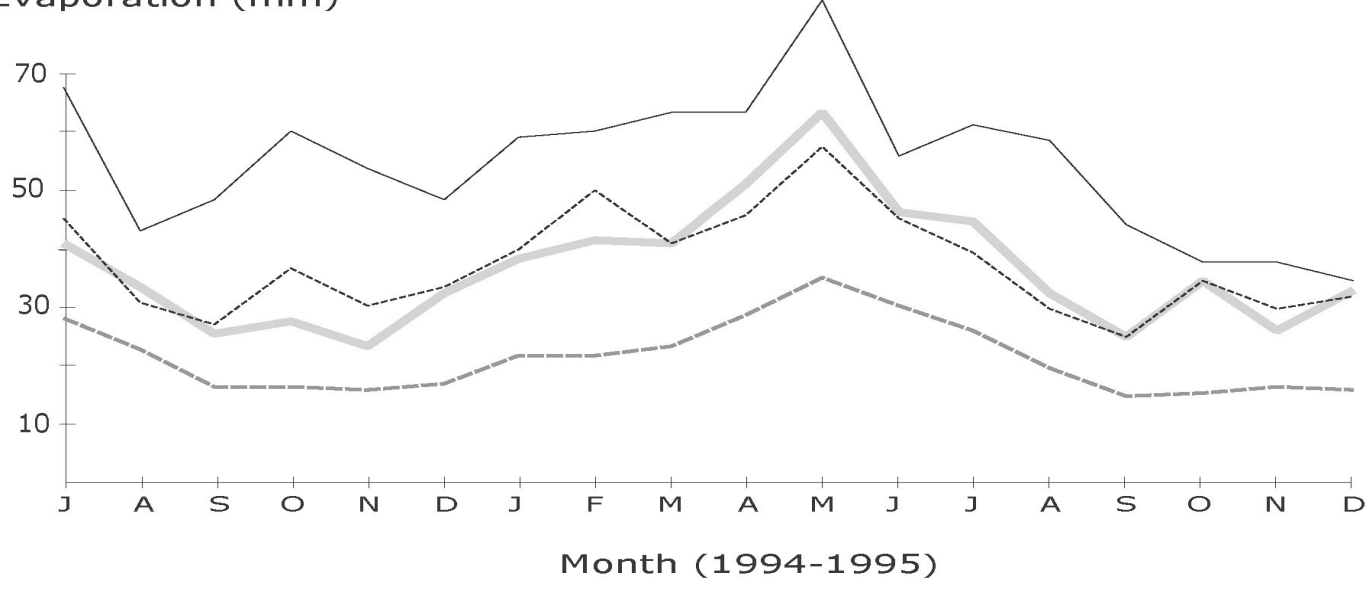

$-\quad$ Station a: signal (fully uncovered)
----- Station b: formation preforest
----
Station c: secondary forest structured formation
Station d: shrub formation

(b)

Humidity

(\%)

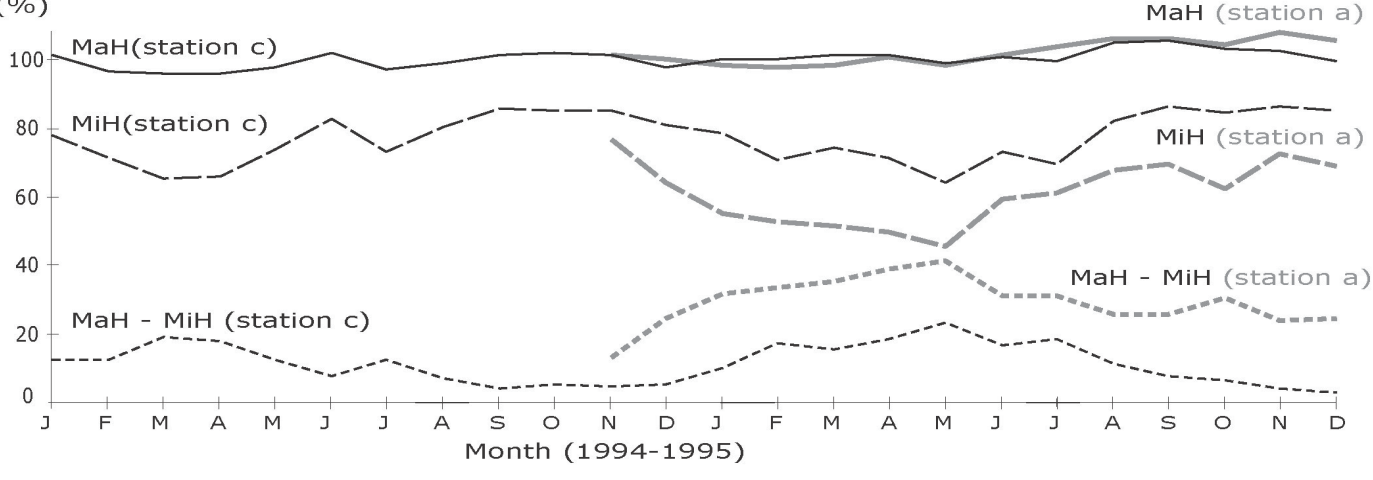

MaH: Maximum Humidity - MiH: Minimum Humidity

Station a: signal (fully uncovered)

Station c: structured secondary forest formation.

(c) 
M.S.D and Humidity (\%)

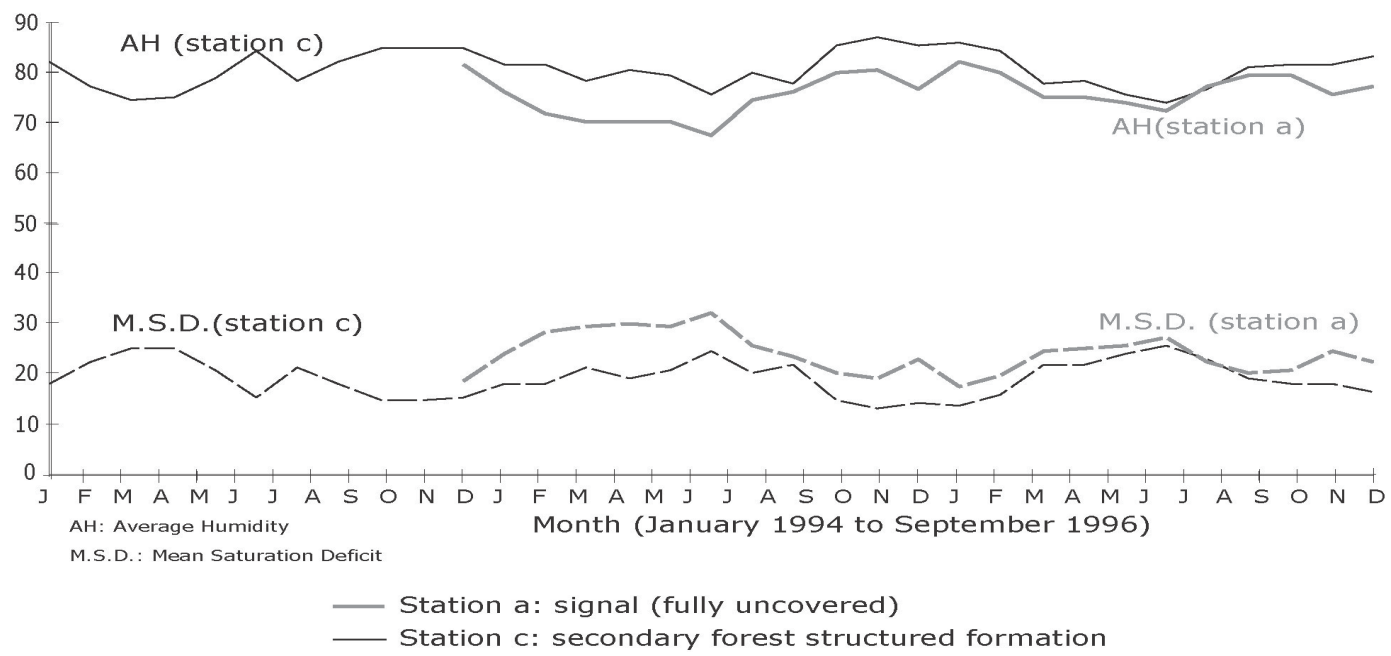

(d)

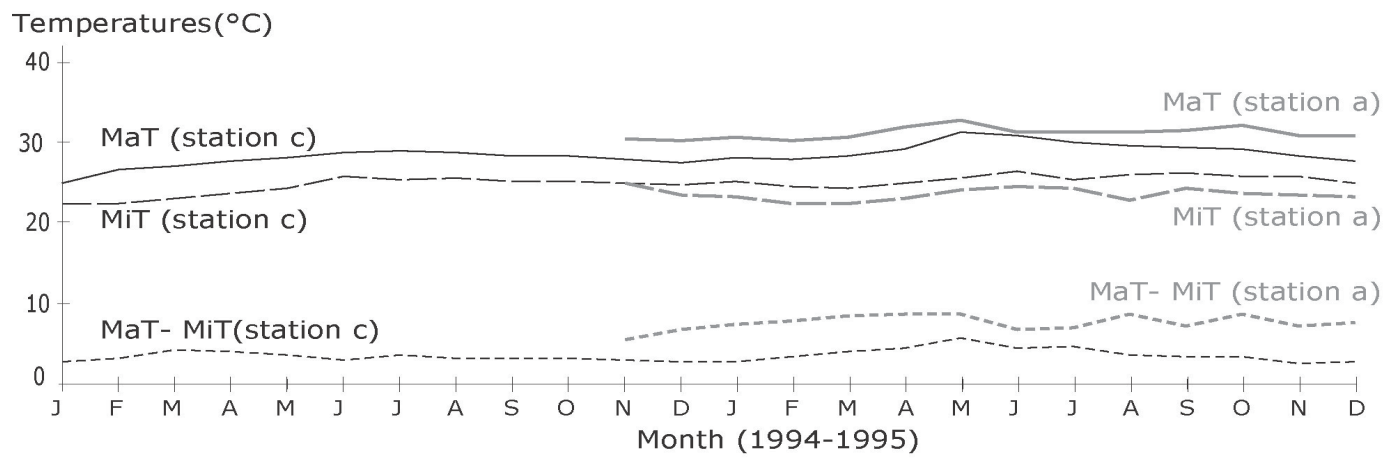

Station a: signal (fully uncovered)

MaT: Maximum Temperature

Station c: secondary forest structured formation

MiT: Minimum Temperature

(e)

Figure 8. (a) Monthly rainfall variations; (b) monthly evaporation (Piche); (c) average monthly humidity; (d) monthly average saturation deficit and average humidity; (e) monthly mean temperature.

formations. The ecosystem potential being of the forest type, the floristic units of the present plant mosaic therefore represent as many dynamic stages as temporal interfaces. The forest ecosystem regression is also accompanied by the simplification of the plant grouping architecture. In fact, unlike the original multi-layer forests (4 or 5 layers), the current secondary phytocenoses are mostly mono-layered and have no impact on the main climate factors. Their phenology is dictated by fluctuations in their external environment. Nowadays, only mature forests ${ }^{15}$ exhibit internal environments with characteristics that differentiate them from the macroclimate. Due to their numerous strata, they significantly change the overall climate factors and create little fluctuating internal environments. These intra-forest microclimates are necessary for the development of specialized ombrophile and helio-ombrophile species. Ultimately, while the vegetation evolves towards the climax, the exchange surfaces increase and become as many interfaces with the external environment. All these specific aspects of the functioning of the Lesser Antilles vegetation are derived from the high degree of biotope heterogeneity which allows for strong biological diversity.

\section{References}

[1] Joseph, P. (2013) How Should the Forest Types of the Lesser Antilles be Described in the Intertropical Area? Earth

\footnotetext{
$\overline{{ }^{15} \text { The rare secondary late, pre-climax and climax forests. }}$
} 
Resources, 1, 78-102. http://dx.doi.org/10.12966/er.09.04.2013

[2] Cachan, P. and Duval, J. (1963) Variations micro-climatiques verticales et saisonnières dans la forêt sempervirente de Basse Côte-d’Ivoire. Annales Faculté des Sciences (Dakar), 8, 89-155.

[3] Aussenac, G. (2000) Interactions between Forest Stands and Microclimate: Ecophysiological Aspects and Consequences for Silviculture. Annals of Forest Science, 57, 287-301. http://dx.doi.org/10.1051/forest:2000119

[4] Chen, J., Saunders, S.C., Crow, T.R., Naiman, R.J., Brosofske, K.D., Mroz, G. D., et al. (1999) Microclimate in Forest Ecosystem and Landscape Ecology Variations in Local Climate Can Be Used to Monitor and Compare the Effects of Different Management Regimes. BioScience, 49, 288-297. http://dx.doi.org/10.2307/1313612

[5] Fetcher, N., Oberbauer, S.F. and Strain, B.R. (1985) Vegetation Effects on Microclimate in Lowland Tropical Forest in Costa Rica. International Journal of Biometeorology, 29, 145-155. http://dx.doi.org/10.1007/BF02189035

[6] Brown, N. (1993) The Implications of Climate and Gap Microclimate for Seedling Growth Conditions in a Bornean Lowland Rain Forest. Journal of Tropical Ecology, 9, 153-168. http://dx.doi.org/10.1017/S0266467400007136

[7] Gray, A.N., Spies, T.A. and Easter, M.J. (2002) Microclimatic and Soil Moisture Responses to Gap Formation in Coastal Douglas-Fir Forests. Canadian Journal of Forest Research, 32, 332-343. http://dx.doi.org/10.1139/x01-200

[8] Weiss, S.B. (2000) Vertical and Temporal Distribution of Insolation in Gaps in an Old-Growth Coniferous Forest. Canadian Journal of Forest Research, 30, 1953-1964. http://dx.doi.org/10.1139/x00-108

[9] Riera, B., Pellissier, R. and Houllier, F. (1998) Caracterisation d'une Mosaique Forestière et de sa Dynamique en Forêt Tropicale Humide Sempervirente. Biotropica, 30, 251-260. http://dx.doi.org/10.1111/j.1744-7429.1998.tb00059.x

[10] Joseph, P. (1997) Dynamique, écophysiologie végétales en bioclimat sec à la Martinique. Thèse de doctorat, Université des Antilles et de la Guyane, Martinique.

[11] Fiard, J.P. (1990) La forêt sèche climacique de la Martinique. In: Actes colloque de botanique, Terre-de-Haut, Les-Saintes, Guadeloupe, 71-85.

[12] Fischer, J., Lindenmayer, D.B. and Manning, A.D. (2006) Biodiversity, Ecosystem Function, and Resilience: Ten Guiding Principles for Commodity Production Landscapes. Frontiers in Ecology and the Environment, 4, 80-86. http://dx.doi.org/10.1890/1540-9295(2006)004[0080:BEFART]2.0.CO;2

[13] Walker, L.R., Wardle, D.A., Bardgett, R.D. and Clarkson, B.D. (2010) The Use of Chronosequences in Studies of Ecological Succession and Soil Development. Journal of Ecology, 98, 725-736. http://dx.doi.org/10.1111/j.1365-2745.2010.01664.x

[14] Putz, F.E. and Redford, K.H. (2010) The Importance of Defining “Forest”: Tropical Forest Degradation, Deforestation, Long-Term Phase Shifts, and Further Transitions. Biotropica, 42, 10-20. http://dx.doi.org/10.1111/j.1744-7429.2009.00567.x

[15] Shaheen, H., Qureshi, R.A. and Shinwari, Z.K. (2011) Structural Diversity, Vegetation Dynamics and Anthropogenic Impact on Lesser Himalayan Sub-Tropical Forests of Bagh District, Kashmir. Pakistan Journal of Botany, 43, 18611866.

[16] Svenning, J.C., Kinner, D.A., Stallard, R.F., Engelbrecht, B.M.J. and Wright, S.J. (2004) Ecological Determinism in Plant Community Structure across a Tropical Forest Landscape. Ecology, 85, 2526-2538. http://dx.doi.org/10.1890/03-0396

[17] Díaz-Varela, R.A., Colombo, R., Meroni, M., Calvo-Iglesias, M.S., Buffoni, A. and Tagliaferri, A. (2010) SpatioTemporal Analysis of Alpine Ecotones: A Spatial Explicit Model Targeting Altitudinal Vegetation Shifts. Ecological Modelling, 221, 621-633. http://dx.doi.org/10.1016/j.ecolmodel.2009.11.010

[18] Burley, S.T., Harper, K.A. and Lundholm, J.T. (2010) Vegetation Composition, Structure and Soil Properties across Coastal Forest-Barren Ecotones. Plant Ecology, 211, 279-296. http://dx.doi.org/10.1007/s11258-010-9789-7

[19] Grytnes, J.A. (2003) Species-Richness Patterns of Vascular Plants along Seven Altitudinal Transects in Norway. Ecography, 26, 291-300. http://dx.doi.org/10.1034/j.1600-0587.2003.03358.x

[20] Heaney, L.R. (2001) Small Mammal Diversity along Elevational Gradients in the Philippines: An Assessment of Patterns and Hypotheses. Global Ecology and Biogeography, 10, 15-39. http://dx.doi.org/10.1046/j.1466-822x.2001.00227.x

[21] Herzog, S.K., Kessler, M. and Bach, K. (2005) The Elevational Gradient in Andean Bird Species Richness at the Local Scale: A Foothill Peak and a High-Elevation Plateau. Ecography, 28, 209-222. http://dx.doi.org/10.1111/j.0906-7590.2005.03935.x

[22] Fiard, J.P. (1994) Les forêts du nord de la montagne Pelée et des édifices volcaniques du piton Mont-Conil et du Morne-Sibérie. Diplôme universitaire de phyto-écologie tropicale et aménagement insulaire, Université des Antilles et de la Guyane, Martinique. 
[23] Stelhe, H. (1936) Essai d'écologie et de géographie botanique. Flore de la Guadeloupe et Dépendances, Tome 1, réédité en 1978 par CALIVRAN REPRINTS, Société Nouvelles des Imprimeries Delmas.

[24] Stelhe, H. (1938) Esquisse des Associations végétales de la Martinique. Imprimerie du Gouvernement, Fort-de-France.

[25] Stehle, H. (1947) La végétation sylvatique de l'archipel Caraïbe. Thèse d’État, Faculté des sciences, Montpellier.

[26] Beard, J.S. (1949) The Natural Vegetation of Windward and Leeward Islands. Oxford Forestry Memories, No. 21, London.

[27] Joseph, P. (2012) The Vegetation of the Lesser Antilles: Floristic Diversity and Ecosystemic Dynamics. International Journal of Environmental Studies, 69, 816-833. http://dx.doi.org/10.1080/00207233.2012.715384

[28] Joseph, P. (2014) Structure of Vegetation Formations and Floral Dynamics in the Lesser Antilles: The Example of the Lower Vegetation Level of Martinique. The Journal of Ecology, 109, 375-400.

[29] Joseph, P. (2015) The Final Stages of Vegetal Dynamics in the Lesser Antilles (A Few Theories). International Journal of Science and Research (IJSR), 4, 1151-1164.

[30] Portecop, J. (1978) Phytogéographie, cartographie écologique et aménagement dans une île tropicale. Le cas de la Martinique. Thèse d'état, université de Grenoble, Grenoble.

[31] Imbert, D. and Portecop, J. (1992) La forêt tropicale semi-décidue de la Guadeloupe: Structures spatiales et production de litière dans la région nord de la Grande-Terre In: Actes colloque de botanique, Terre-de-Haut, Les Saintes, Guadeloupe, 53-70.

[32] Doyle, T.W. (1981) The Role of Disturbance in the Gap Dynamics of a Montane Rain Forest: An Application of a Tropical Forest Succession Model. In: West, D.C., Shugart, H.H. and Botkin, D.B., Eds., Forest Succession, Springer, New York, 56-73. http://dx.doi.org/10.1007/978-1-4612-5950-3_6

[33] Lugo, A.E., Medina, E., Trejo-Torres, J.C. and Helmer, E. (2006) ЛСГ Botanical and Ecological Basis for the Resilience of Antillean Dry Forests. Neotropical Savannas and Seasonally Dry Forests: Plant Diversity, Biogeography, and Conservation.

[34] O’Brien, E.M. (1993) Climatic Gradients in Woody Plant Species Richness: Towards an Explanation Based on an Analysis of Southern Africa's Woody Flora. Journal of Biogeography, 20, 181-198. http://dx.doi.org/10.2307/2845670

[35] Rahbek, C. (1995) The Elevational Gradient of Species Richness: A Uniform Pattern? Ecography, 18, $200-205$.

[36] Bastien-Henri, S., Park, A., Ashton, M. and Messier, C. (2010) Biomass Distribution among Tropical Tree Species Grown under Differing Regional Climates. Forest Ecology and Management, 260, 403-410. http://dx.doi.org/10.1016/j.foreco.2010.04.035

[37] Kent, M. (2011) Vegetation Description and Data Analysis: A Practical Approach. John Wiley \& Sons, New York.

[38] Hessler, I., Dupont, L., Bonnefille, R., Behling, H., González, C., Helmens, K.F., et al. (2010) Millennial-Scale Changes in Vegetation Records from Tropical Africa and South America during the Last Glacial. Quaternary Science Reviews, 29, 2882-2899. http://dx.doi.org/10.1016/j.quascirev.2009.11.029

[39] Rollet, B., Högermann, C. and Roth, I. (2012) Stratification of Tropical Forests as Seen in Leaf Structure. Volume 21, Springer Science \& Business Media, New York.

[40] Terborgh, J. (1985) The Vertical Component of Plant Species Diversity in Temperate and Tropical Forests. American Naturalist, 126, 760-776. http://dx.doi.org/10.1086/284452

[41] Smith, A.P. (1973) Stratification of Temperature and Tropical Forests. American Naturalist, 107, 671-683. http://dx.doi.org/10.1086/282866

[42] Bouton, J. (1640) Relation de l'établissement des Français depuis l'an 1635 en l'île de la Martinique: L’une des Antilles de l’Amérique. Reprod. en fac. sim. de l'éd. de Paris, S. Cramoisy.

[43] Labat, J.B. (1972-1974) Nouveau voyage aux Iles d’Amérique. Edition des Horizons Caraïbes, 4 Vol. (Réimpression de l'édition de 1742), Fort-de-France.

[44] Kimber, C.T. (1988) Martinique Revisited. Texas University Press, College Station.

[45] Moreau, J.P. (1987) Un flibustier dans la mer des Antilles: 1618-1620, manuscrit inédit du début du XVI ${ }^{\mathrm{Ie}}$ siècle. Publ. par J.P.MOREAU, préf. de J. MEYER. Collection BiBliographique, Clamart.

[46] Pardon, N. (1877) La Martinique depuis sa découverte jusqu’à nos jours. Challamel, Paris.

[47] Pinchon, R.P. (1961) Description de l’Ile de Saint-Vincent: Manuscrit anonyme du XVIII ${ }^{\mathrm{e}}$ siècle. Bulletin de la Société d'Histoire de la Martinique, 9, 31-81.

[48] Rochefort, C. (1667) Histoire naturelle des îles Antilles de l’Amérique. C. Fourmy, Lyon.

[49] Tardy, C. (1998) Paléo-incendies naturels, feux anthropiques et environnements forestiers en Guyane française: 
Approches chronologiques et anthracologiques. Thèse nouveau régime, Université de Montpellier 2, Montpellier.

[50] Hatzenberger, F. (1994) Paysages et végétations des Antilles. Karthala, Paris.

[51] UNESCO (1973) Classification internationale et cartographie de la végétation. UNESCO, Paris.

[52] Li, Y., Zu, Y., Wu, B., Gao, G. and Guo, F. (2013) Forest Diversity and Community Dynamics along an Altitudinal Gradient of Ailaoshan Mountain (Yuanyang, Yunnan Province, China). Journal of Environmental Engineering and Landscape Management, 21, 96-105. http://dx.doi.org/10.3846/16486897.2012.695735

[53] Montgomery, R.A. and Chazdon, R.L. (2001) Forest Structure, Canopy Architecture, and Light Transmittance in Tropical Wet Forests. Ecology, 82, 2707-2718. http://dx.doi.org/10.1890/0012-9658(2001)082[2707:FSCAAL]2.0.CO;2

[54] Finkelstein, D. (1982 ) Evolution comparée des microclimats en coupe rase, sous recrû naturel et sous forêt primaire sur la parcelle Arbocel. Bull. Liaison Ecerex, ORSTOM-Guyane, No. 6, 19-32.

[55] Kobe, R.K. (1999) Light Gradient Partitioning among Tropical Tree Species through Differential Seedling Mortality and Growth. Ecology, 80, 187-201. http://dx.doi.org/10.1890/0012-9658(1999)080[0187:LGPATT]2.0.CO;2 